\title{
Preparation, characterization, in vivo and in vitro studies of arsenic trioxide Mg-Fe ferrite magnetic nanoparticles
}

\author{
Guo-fu YANG ${ }^{1, \#}$, Xiang-hui $\mathrm{LI}^{2, \#}$, Zhe ZHAO ${ }^{1}$, Wen-bo WANG ${ }^{1, *}$ \\ ${ }^{1}$ Department of Orthopaedics, the First Affiliated Hospital of Harbin Medical University, Harbin 150001, China; ${ }^{2}$ Department of Phar- \\ macy, the Second Affiliated Hospital of Harbin Medical University, Harbin 150001, China
}

\begin{abstract}
Aim: $\mathrm{MgFe}_{2} \mathrm{O}_{4}$ magnetic nanoparticle composed of $\mathrm{As}_{2} \mathrm{O}_{3}\left(\mathrm{As}_{2} \mathrm{O}_{3}-\mathrm{MNPS}\right)$ were prepared and their in vitro and in vivo characteristics were studied.

Methods: The solvent-displacement method was applied for preparation of the nanoparticle using Poly-D,L-lactic-co-glycolic acid(PLGA). The characteristics studies of the products included magnetic response, morphology (transmission electron microscopy and scanning electron microscopy), entrapment efficiency, drug loading, particle sizes, zeta potential, in vitro drug release and tissue magnetic targeting. Nanoparticle cytotoxicity to Saos-2 cells was investigated using the MTT assay. To guide the external magnetic field in the liver, the concentration of $\mathrm{As}_{2} \mathrm{O}_{3}$ in the liver and kidney was measured using an atomic fluorescence spectrometer after injecting $\mathrm{As}_{2} \mathrm{O}_{3}-\mathrm{MNPs}$ into the caudal veins of mice.

Results: The $\mathrm{As}_{2} \mathrm{O}_{3}$-MNPs were approximately spherical. The average diameter, drug loading, entrapment efficiency and zeta potential of $\mathrm{As}_{2} \mathrm{O}_{3}$-MNPs were $109.9 \mathrm{~nm}, 10.08 \%, 82.16 \%$, and $-14.33 \mathrm{mV}$, respectively. The specific saturation magnetism was $8.65 \mathrm{emu} / \mathrm{g}$. In vivo, the concentration of $\mathrm{As}_{2} \mathrm{O}_{3}$ in the liver was significantly higher than that in the non-magnetic group. While the concentration of $\mathrm{As}_{2} \mathrm{O}_{3}$ in the kidney was lower than that in the non-magnetic group. The $C_{\max }$ in liver tissue in the magnetic group was $30.65 \mu \mathrm{g} / \mathrm{g}$, which was 4.17 times the drug concentration in the same group in kidney tissue $(7.35 \mu \mathrm{g} / \mathrm{g})$ and 2.88 times the concentration of drug $(10.66 \mu \mathrm{g} / \mathrm{g})$ in the liver tissue of the non-magnetic group.

Conclusion: The PLGA polymer-loaded magnetic nanoparticle composed of arsenic trioxide can be magnetically targeted well and applied in biomedicine.
\end{abstract}

Keywords: $\mathrm{As}_{2} \mathrm{O}_{3}$; PLGA; magnetic nanoparticle; Mg-Fe ferrite; targeting

Acta Pharmacologica Sinica (2009) 30: 1688-1693; doi: 10.1038/aps.2009.158

\section{Introduction}

Arsenic trioxide (ATO), known as Pi Shuang, has been used in traditional Chinese medicine for thousands of years. Approximately 100 years ago, Western medicine adopted some of the arsenic compounds and used them widely ${ }^{[1]}$, but subsequently abandoned them because of their toxic and oncogenic effects after chronic exposure. Despite the toxicity of arsenic, ATO has long been of biomedical interest. Recently, it has been shown to be efficient in the treatment of newly diagnosed and relapsed acute promyelocytic leukemia ${ }^{[2-5]}$. More interestingly, this anticancer efficiency of ATO was extended to many solid tumors ${ }^{[6,7]}$, and ATO has been shown to induce apoptosis

\footnotetext{
\# These authors contributed equally to this work.

* To whom correspondence should be addressed.

E-mail wangwwbo@yahoo.com.cn

Received 2009-08-30 Accepted 2009-09-25
}

in various malignant tumor cells ${ }^{[8,9]}$. Meanwhile, to avoid the toxicity and side effects of ATO, many new preparations for this powerful drug have received significant attention.

In this study, ATO was incorporated into Poly- $D, L$-lacticco-glycolic acid(PLGA) magnesium iron ferrite $\left(\mathrm{MgFe}_{2} \mathrm{O}_{4}\right.$, $\mathrm{MgO} \cdot \mathrm{Fe}_{2} \mathrm{O}_{3}$ ) magnetic nanoparticles. We hypothesize that they can achieve site-specific delivery guided by an external magnetic field, and then can subsequently be released in the target tissue to provide enhanced therapeutic efficacy and reduced side effects. The $\mathrm{As}_{2} \mathrm{O}_{3}$ magnetic nanoparticles $\left(\mathrm{As}_{2} \mathrm{O}_{3}-\mathrm{MNPs}\right)$ were prepared using a solvent-displacement method, and their loading efficiency, characterization, in vitro drug release, cytotoxicity and in vivo magnetic targeting were investigated.

\author{
Materials and methods \\ Drugs and reagents \\ Poly-D,L-lactic-co-glycolic acid (PLGA; lactic-glycolic acid
}


ratio: $50: 50, M_{\mathrm{r}}$ (relative molecular mass $)=20000$, batch number: 070512) was purchased from Shanghai Pharmaceutical Industry Research Institute. Magnesium iron ferrite $\left(\mathrm{MgFe}_{2} \mathrm{O}_{4}\right.$, $10 \mathrm{~nm}$ ) was a gift from the Inorganic Department of Beijing Chemical Technology University. $\mathrm{As}_{2} \mathrm{O}_{3}$ was provided by Sigma Corporation. MTT (5-dimethylthiazol-2-yl-2,5-diphenyltetrazolium bromide), McCoy's 5A and FBS were purchased from Gibco Corporation. Other reagents and chemicals were of AR (analytical reagent) grade and were from standard commercial sources.

\section{Animals}

Kunming mice (Grade II, Certificate No 0805192) weighing 18-22 g were provided by Animal Laboratory Center of the Second Affiliated Hospital of Harbin Medical University.

\section{Preparation of $\mathrm{As}_{2} \mathrm{O}_{3}-\mathrm{MNPs}$}

$\mathrm{As}_{2} \mathrm{O}_{3} \mathrm{MgFe}_{2} \mathrm{O}_{4}$ magnetic nanoparticles ( $\mathrm{As}_{2} \mathrm{O}_{3}$-MNPs) were prepared using a solvent-displacement method ${ }^{[10]}$. Briefly, exactly $35 \mathrm{mg}$ of PLGA was dissolved in a mixture of $5 \mathrm{mg} / \mathrm{mL}$ $\mathrm{As}_{2} \mathrm{O}_{3}$ liquid $(1 \mathrm{~mL})$, using acetone $(9 \mathrm{~mL})$ as a solvent phase after clarification. A gelatin solution $(40 \mathrm{~mL}, \omega=0.01)$ was stirred and heated in a $65{ }^{\circ} \mathrm{C}$ water bath for $30 \mathrm{~min}$. A small amount of $\mathrm{MgFe}_{2} \mathrm{O}_{4}$ was added to a volume of $0.5 \%$ Tween 80 to achieve a final concentration of $0.05 \mathrm{mg} / \mathrm{mL}$. After $10 \mathrm{~min}$ of ultrasonic dispersion, the non-solvent phase was created. With mixing and ultrasonic dispersion, the solvent phase (60 drops/s) was infused into the non-solvent phase. The mixture was stirred until the acetone had evaporated, and the resultant dispersed nanoparticle solution was condensed in a rotary evaporator and filtered through a $0.4 \mu \mathrm{m}$ filter (Millex AP, Millipore). The magnetic nanoparticles were collected by centrifugation at $30000 \times g$ at $4{ }^{\circ} \mathrm{C}$ for $40 \mathrm{~min}$ and washed twice with double distilled water before lyophilization. Finally, the samples were frozen for $3 \mathrm{~h}$ at $-20{ }^{\circ} \mathrm{C}$ and freeze-dried for $48 \mathrm{~h}$ in a $10 \mathrm{~mL}$ freeze-drying vial (initial self-temperature was $-15{ }^{\circ} \mathrm{C}$; the temperature was reduced to $-40{ }^{\circ} \mathrm{C}$ and maintained for $48 \mathrm{~h}$ ). The temperature of the vial was then elevated to $15^{\circ} \mathrm{C}$, and the vial was removed.

\section{Characterization of $\mathrm{As}_{2} \mathrm{O}_{3}$-loaded magnetic nanoparticles Investigation of the magnetic response ${ }^{[11]}$}

To investigate the magnetic properties of the $\mathrm{As}_{2} \mathrm{O}_{3}-\mathrm{MNPs}$, magnetic measurements were made at room temperature (23 ${ }^{\circ} \mathrm{C}$ ), according to particle size, using a vibrating sample magnetometer (VSM, JDM-13) at -15 kOe-15 kOe.

\section{Determination of the polydispersibility and zeta potential ${ }^{[12]}$}

Polydispersibility and zeta potential were measured with the laser light scattering particle size analyzer (PSS380, PSS company, US). The $\mathrm{As}_{2} \mathrm{O}_{3}$-MNPs were transferred in lyophilized form to $2 \mathrm{~mL}$ Eppendorf tubes. The samples were suspended in phosphate buffer, $\mathrm{pH} 7.4$, and then introduced into the instrument according to the manufacturer's guidelines. The particle size and zeta potential were then read.
Observation of the morphology by scanning electron microscopy (SEM) and transmission electron microscopy (TEM)

The size and surface morphology of the MNPs were determined by scanning electron microscopy (JSM561OLV, Japanese Electronic Company). The samples were spread on metal stubs and gold coating was added using an ion-sputtering device. The gold-coated samples were vacuum-dried and then examined.

Transmission electron microscopy (1220, Japan Electronic Company) was performed on $\mathrm{As}_{2} \mathrm{O}_{3}$-MNPs. A drop of drugloaded magnetic nanoparticle suspension mixed with distilled water was placed on a carbon film coated on a copper grid for TEM. Observation was done at $80.0 \mathrm{kV}$.

\section{Entrapment efficiency}

Loaded drug quantity was determined according to the following procedure: after the $\mathrm{As}_{2} \mathrm{O}_{3}$-MNPs were synthesized, unbound arsenic trioxide was separated by centrifugation at $30000 \times g$ at $4{ }^{\circ} \mathrm{C}$ for $30 \mathrm{~min}$. The precipitate was then lyophilized, and the resulting powder containing the loaded magnetic nanoparticles was dissolved in water to obtain a clear solution. Using hydride generation atomic fluorescence spectrometry (AFS-230E Atomic Fluorescence Spectrometer, Beijing HaiGuang Instruments Company), the presence of arsenic was determined. Loading capacity was expressed in terms of entrapped drug quantity and entrapment efficiency ${ }^{[13]}$.

\section{In vitro drug release}

The in vitro release experiments were carried out as follows: $20 \mathrm{mg}$ of arsenic-loaded magnetic nanoparticles and $1 \mathrm{~mL}$ of phosphate buffered saline (PBS $0.1 \mathrm{~mol} / \mathrm{L}, \mathrm{pH} 7.4$ ) were mixed in a dialysis tube (27-mm diameter; Sigma Chemical Co), and the tube was then introduced into a vial containing $10 \mathrm{~mL}$ of PBS. At specific time intervals, the solution in the vial was removed and replaced with fresh PBS. The concentration of the released arsenic trioxide was determined by atomic fluorescence spectrometry.

\section{Cytotoxicity evaluation}

Cell line and cell culture

The human osteosarcoma cell line, Saos-2, was obtained from the China Center for Type Culture Collection of Wuhan University. The Saos-2 cell line was cultured in McCoy's 5A medium containing 15\% fetal bovine serum (Gibco), $2 \mu \mathrm{mol} / \mathrm{L}$ L-glutamine, $100 \mathrm{U} / \mathrm{mL}$ penicillin, and $100 \mu \mathrm{g} / \mathrm{mL}$ streptomycin (Gibco) at $37^{\circ} \mathrm{C}, 5 \% \mathrm{CO}_{2}$ with high humidity. The cells were passaged every $2-3$ days using $0.05 \%$ trypsin (Gibco) in $0.01 \%$ EDTA (Sigma Aldrich).

\section{MTT assay}

For cell growth and viability assays, $5 \times 10^{4}$ cells $/ \mathrm{mL}$ were plated into six-well flat-bottom plates (Costar). The cells were cultured in different concentrations of $\mathrm{As}_{2} \mathrm{O}_{3}$, with or without $\mathrm{As}_{2} \mathrm{O}_{3}$ loaded MNPs or McCoy's 5A medium to measure their growth and viability. All flat-bottom plates were then placed in a magnetic field with a magnetic flux density of 
$0.5 \mathrm{~T}$. Based on these results, different concentrations of $\mathrm{As}_{2} \mathrm{O}_{3}$ and $\mathrm{As}_{2} \mathrm{O}_{3}$-loaded MNPs were compared to find the optimal concentration to kill tumor cells. After incubation for 48 h, 20 $\mu \mathrm{L}$ of MTT solution $(5 \mathrm{mg} / \mathrm{mL})$ was added into each well, and the cells were incubated at $37^{\circ} \mathrm{C}$ in the dark for at least $4 \mathrm{~h}$. Formazan crystals were solubilized in $200 \mu \mathrm{L}$ of dimethyl sulfoxide (DMSO) in every well, and the absorbance was read at $540 \mathrm{~nm}$ using a plate reader (Model 550, Bio-Rad). The inhibition ratio of cells was determined as follows: (1-Absorbance of drug-treated cells/Absorbance of control ) $\times 100 \%$. Each assay was repeated at least five times ${ }^{[14]}$.

\section{Animal experiments}

\section{Magnetic targeting in mice}

Five-week-old male mice (18-22 g) were housed with free access to a standard diet and water for 1 week, and then they were fasted overnight before experimentation. Experiments were carried out in accordance with the guidelines of the Chinese Committee for Experiments on Animals. Eighty mice were randomly divided into two groups $(n=40)$ and then anesthetized with an intraperitoneal (ip) injection of pentobarbitone $(50 \mathrm{mg} / \mathrm{kg})$. The livers of the mice in one group were exposed and positioned in an external magnetic field with a magnetic flux density of $0.5 \mathrm{~T}$ for $30 \mathrm{~min}$, whereas the livers from the other group were treated without a magnetic field. The tail veins in the two groups were all injected with magnetic nanoparticles $(5 \mathrm{mg} / \mathrm{kg})$. Eight groups of five mice each were sacrificed $15 \mathrm{~min}, 30 \mathrm{~min}, 1 \mathrm{~h}, 2 \mathrm{~h}, 4 \mathrm{~h}, 8 \mathrm{~h}, 16 \mathrm{~h}$, and $24 \mathrm{~h}$ after the injection. The livers and kidneys were excised, rinsed in normal saline, and weighed, and then the amounts of $\mathrm{As}_{2} \mathrm{O}_{3}$ in the livers and kidneys were measured by atomic absorption spectrometry.

\section{Statistical analysis}

Results are presented as the mean $\pm \mathrm{SD}$. Determination of the significance of differences between the two groups was carried out using Student's $t$-test and considered statistically significant for values of $P<0.05$.

\section{Results}

\section{Magnetic response}

The superparamagnetic behavior of the $\mathrm{As}_{2} \mathrm{O}_{3}$-MNPs was evident due to their zero coercivity and remanence on the magnetization loop, and a saturation magnetization of $8.65 \mathrm{emu} \cdot \mathrm{g}^{-1}$ was determined (Figure 1). The results showed a strong magnetic response of the $\mathrm{As}_{2} \mathrm{O}_{3}$-MNPs.

\section{Polydispersibility and zeta potential}

The results of particle size analysis by laser diffraction showed that the most dense and narrow range of particle dispersion was observed between $60 \mathrm{~nm}$ and $180 \mathrm{~nm}$. Average particle diameter was $109.9 \mathrm{~nm}$ (Figure 2). The $\mathrm{As}_{2} \mathrm{O}_{3}$-MNPs had a negative zeta potential value of $-14.33 \mathrm{mV}$.

The SEM and TEM studies showed that the prepared particles

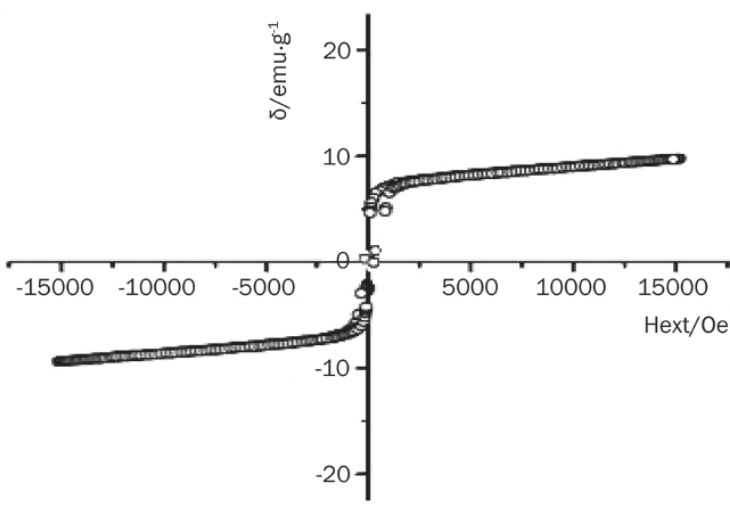

Figure 1. Hysteresis loops of $\mathrm{As}_{2} \mathrm{O}_{3}$-MNPs.

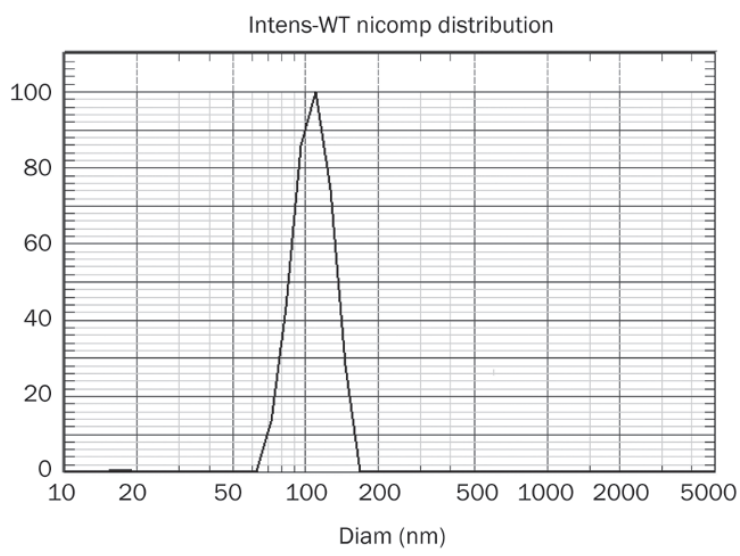

Figure 2. Nicomp distribution of $\mathrm{As}_{2} \mathrm{O}_{3}-\mathrm{MNPs}$.

were smooth and spherical-shaped, with sizes in the nano range. A major portion of the particles consisted of very small particles in nano-range size compared with the larger particles, which were less than $200 \mathrm{~nm}$ in size. This was further confirmed by particle size analysis, which showed that size distribution varied from $60 \mathrm{~nm}$ to $180 \mathrm{~nm}$. There was a clear distribution of the small and large particles and they were not conglomerated (Figure 3, 4).

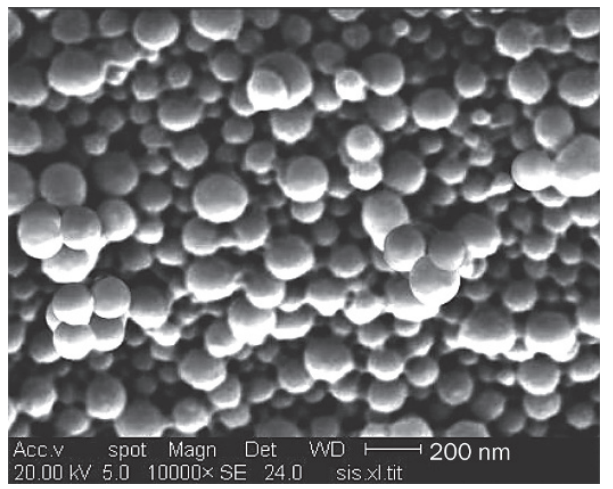

Figure 3. Scanning electron micrograph of $\mathrm{As}_{2} \mathrm{O}_{3}-\mathrm{MNPs}$. 


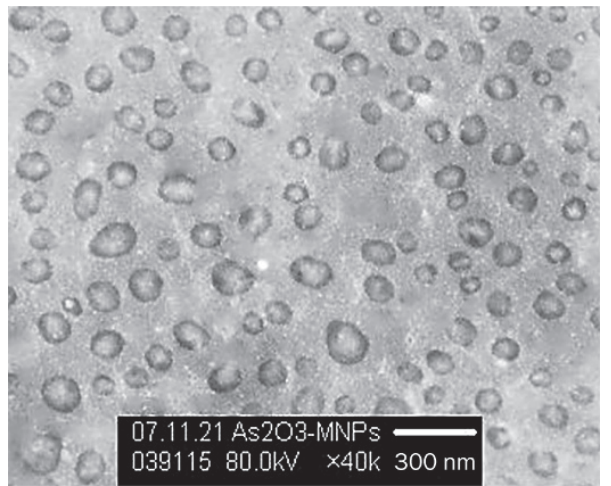

Figure 4. Transmission electron micrograph of $\mathrm{As}_{2} \mathrm{O}_{3}-\mathrm{MNPs}$.

Entrapment efficiency, drug loading and in vitro release study The encapsulation efficiency value achieved for arsenic trioxide was $82.16 \%$; the arsenic trioxide loading content or loading efficiency onto the $\mathrm{As}_{2} \mathrm{O}_{3}$-MNPs was $10.08 \%$. Total release of arsenic trioxide from $\mathrm{As}_{2} \mathrm{O}_{3}$-MNPs is shown in Figure 5. Regarding the release pattern of the samples, a pseudo zeroorder release after an initial burst release effect was observed. The release rate of $\mathrm{As}_{2} \mathrm{O}_{3}$ from $\mathrm{As}_{2} \mathrm{O}_{3}$-MNPs was moderate at about $50 \%$ at $24 \mathrm{~h}$, compared with the rapid release rate of $98 \%$ from the $\mathrm{As}_{2} \mathrm{O}_{3}$ solution at $24 \mathrm{~h}$.

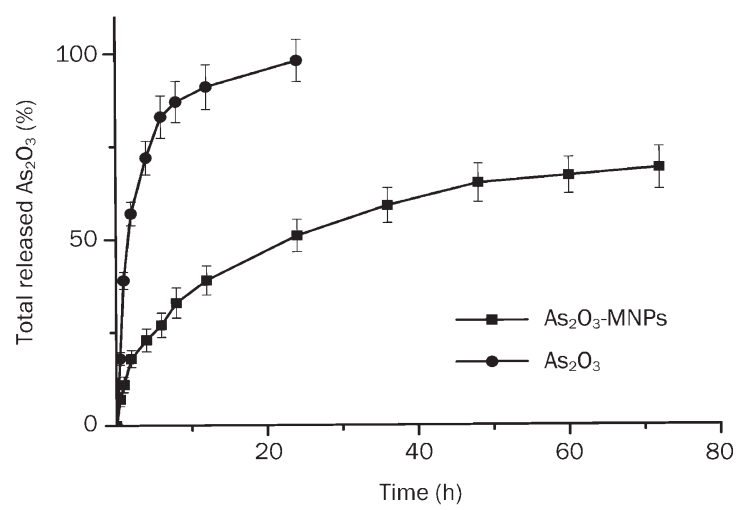

Figure 5. Release of $\mathrm{As}_{2} \mathrm{O}_{3}$ from $\mathrm{As}_{2} \mathrm{O}_{3}-\mathrm{MNPs}$ at $\mathrm{pH} 7.4,37^{\circ} \mathrm{C}$. Mean $\pm \mathrm{SD}$. $n=3$.

\section{Cell growth and inhibition}

The MTT assay (Figure 6, 7) revealed that without $\mathrm{As}_{2} \mathrm{O}_{3}$, the MNPs alone could hardly inhibit the Saos-2 cell proliferation at doses between $12.5 \mu \mathrm{g}$ and $75 \mu \mathrm{g}(P>0.95)$. The growth inhibition of Saos- 2 cells was dose-dependent, and the $50 \%$ inhibition concentration $\left(\mathrm{IC}_{50}\right)$ at $48 \mathrm{~h}$ was $5.54 \mu \mathrm{mol} / \mathrm{L}$. The inhibition of Saos- 2 cells in the $\mathrm{As}_{2} \mathrm{O}_{3}$-MNP group was significantly higher than that in the $\mathrm{As}_{2} \mathrm{O}_{3}$ group. The $\mathrm{IC}_{50}$ of the $\mathrm{As}_{2} \mathrm{O}_{3}$ MNPs group at $48 \mathrm{~h}$ was $2.15 \mu \mathrm{mol} / \mathrm{L}$, which was 2.57-fold lower than that in the $\mathrm{As}_{2} \mathrm{O}_{3}$ groups $(P<0.05)$, suggesting that the effective rate was 2.57 .

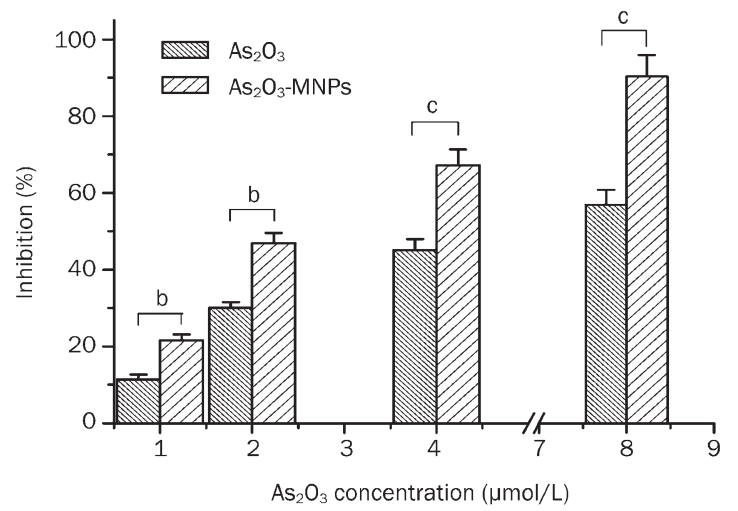

Figure 6. Growth inhibition rates of Saos-2 cells incubated with different concentrations of $\mathrm{As}_{2} \mathrm{O}_{3}$ and $\mathrm{As}_{2} \mathrm{O}_{3}-\mathrm{MNPs}$ for $48 \mathrm{~h}$ as assessed by the MTT assay. Mean \pm SD. $n=5 .{ }^{b} P<0.05,{ }^{\circ} P<0.01$.

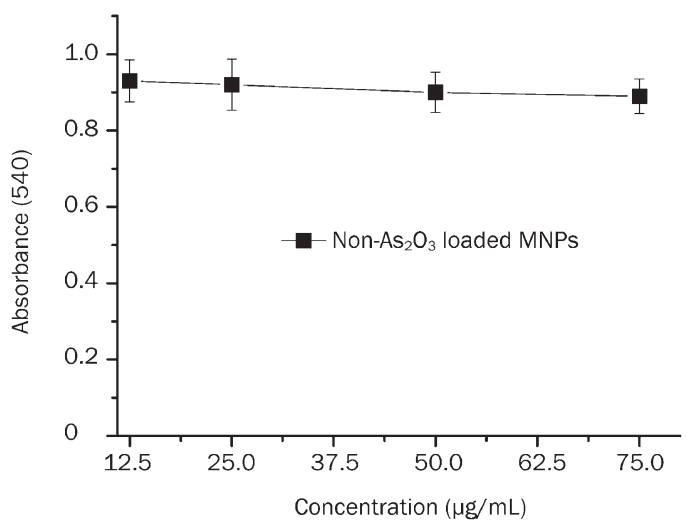

Figure 7. Absorbance of Saos-2 cells incubated with different concentrations of non- $\mathrm{As}_{2} \mathrm{O}_{3}$-loaded MNPs for $48 \mathrm{~h}$ as assessed by the MTT assay. Mean \pm SD. $n=5$.

\section{Concentration of $\mathrm{As}_{2} \mathrm{O}_{3}$ in liver and kidney tissue}

After administration of $\mathrm{As}_{2} \mathrm{O}_{3}$-MNPs (to $\mathrm{As}_{2} \mathrm{O}_{3}$ total content) at $5 \mathrm{mg} / \mathrm{kg}$ body weight, the liver tissue concentrationtime curve was determined, as shown in Figure 8. The $C_{\max }$ of $\mathrm{As}_{2} \mathrm{O}_{3}$ in the liver tissue in group $\mathrm{A}$ was $30.65 \mu \mathrm{g} / \mathrm{g}, 4.17$ times the drug concentration in the kidney tissue from the same experimental group $(7.35 \mu \mathrm{g} / \mathrm{g})$ and 2.88 times the drug concentration in the liver tissue in group B $(10.66 \mu \mathrm{g} / \mathrm{g})$. The drug concentration in the liver tissue in the $24 \mathrm{~h}$ group was $2.13 \mu \mathrm{g} / \mathrm{g}, 4.63$ times the concentration of drug in the kidney tissue $(0.46 \mu \mathrm{g} / \mathrm{g})$, while the liver drug concentration in group $\mathrm{B}$ was only $0.26 \mu \mathrm{g} / \mathrm{g}$. In group A liver tissue, which was injected with the highest concentration of drug, the drug concentration in the tissue was maintained for an extended period of time; group B liver tissue, which received a lower concentration of drug, cleared the drug in a much shorter time.

SPSS 12.0 statistical analysis revealed that in the magnetic field group and non-magnetic group, there was a significant difference in the concentration of $\mathrm{As}_{2} \mathrm{O}_{3}$ between the liver and 


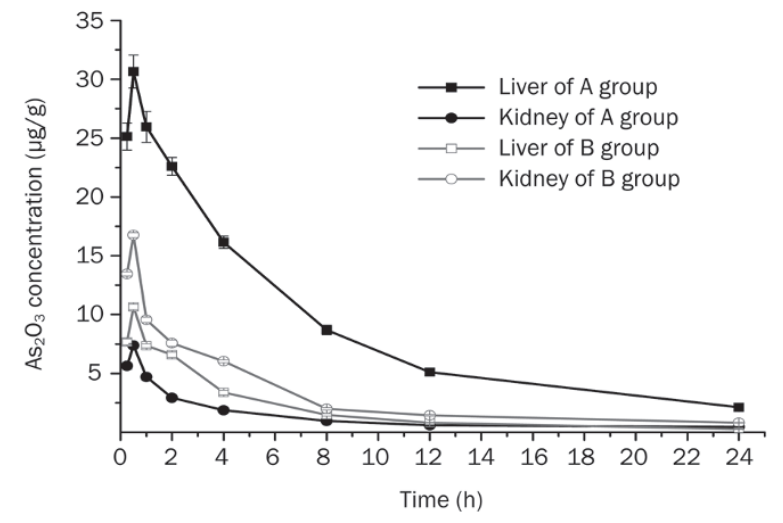

Figure 8. $\mathrm{As}_{2} \mathrm{O}_{3}$ concentrations in liver and kidney. (A) Magnetic group; (B) Non-magnetic group.

kidney tissues $(P<0.01)$. In the magnetic field group, the drug concentrations were significantly higher in the liver than in the kidney $(P<0.01)$. In the non-magnetic group, there was also a significant difference in the concentrations of $\mathrm{As}_{2} \mathrm{O}_{3}$ between the liver and the kidney $(P<0.05)$, with lower drug concentrations in the liver.

\section{Discussion}

It is a major breakthrough that acute promyelocytic leukemia can be cured by arsenic trioxide (ATO), although the clinical dose of ATO could induce severe cardiac injuries, such as QT prolongation, arrhythmias, and cardiac arrest in extreme cases. Other adverse effects include skin lesions, gastrointestinal symptoms, neuropathy and liver dysfunction ${ }^{[15,16]}$. Therefore, we decided to evaluate magnetic nanoparticles made with ATO in an effort to reduce the side effects of ATO and improve its bioavailability.

PLGA, a biodegradable and biocompatible polymer approved for humans ${ }^{[17]}$, was used to prepare $\mathrm{As}_{2} \mathrm{O}_{3}$ magnetic nanoparticles. At present, the most widely used method in the preparation of PLGA nanoparticles is the emulsion solvent evaporation method. However, multiple organic solvents are needed for this method, which would result in larger-size nanoparticles and a wide range of particle size distributions ${ }^{[18]}$. Furthermore, $\mathrm{As}_{2} \mathrm{O}_{3}$ has a low solubility in water. If this limitation was overcome in the preparation of magnetic nanoparticles, the particle size, drug loading, entrapment efficiency and stability would be improved.

However, in the application of magnetic nanoparticles, there are still some unanswered questions. First, although the method utilized in the present study of preparing $\mathrm{As}_{2} \mathrm{O}_{3}-\mathrm{MNPs}$ results in a sufficient number of packets of magnetic material, the number of packets of MNPs in each batch of $\mathrm{As}_{2} \mathrm{O}_{3}$-MNPs cannot be quantified. Second, a stable, well-focused, suitable magnetic field strength needs to be determined. Furthermore, a methodology of the magnetic material to reduce the toxicity and enhance its compatibility with the human body needs to be discovered.

The solvent displacement method was used in this study to prepare $\mathrm{As}_{2} \mathrm{O}_{3}$-MNPs. $\mathrm{As}_{2} \mathrm{O}_{3}$ in an aqueous solution was mixed with acetone in a 1:9 ratio. PLGA was then dissolved in this solution and a surfactant containing the aqueous phase was added with stirring to remove the volatile organic solvent. $\mathrm{As}_{2} \mathrm{O}_{3}$ is not soluble in acetone, but it exists in the arsenite form $\left(\mathrm{H}_{3} \mathrm{AsO}_{3}\right)$ in water; the carbonyl group in acetone $(\mathrm{C}=\mathrm{O})$ associates to form stable hydrogen bonds, resulting in a stable phase of the solvent.

The stability of nanoparticle dispersion is dependent not only on the size but also on the steric repulsion, gravity, Brownian motion forces and electrostatic repulsion, and other factors. Taking these factors into consideration, we investigated whether PLGA may help to enhance the surface properties of magnetic nanoparticles, because surface properties are crucial for nanoparticle applications ${ }^{[19]}$. For this purpose, zeta potential measurements were carried out to estimate the effect of PLGA on the surface charge of $\mathrm{As}_{2} \mathrm{O}_{3}$-MNPs. The zeta potential reported for PLGA-based magnetic nanoparticles was found to be $-14.33 \mathrm{mV}$, which indicated that deprotonated carboxylates $\left(\mathrm{COO}^{-}\right)$are on the surface of nanoparticles and thus make them negatively charged. Particles with zeta potentials higher than $+30 \mathrm{mV}$ and lower than $-30 \mathrm{mV}$ are normally considered stable for colloidal dispersion ${ }^{[20]} . \quad \mathrm{As}_{2} \mathrm{O}_{3}$-loaded MNPs are therefore probably unstable in the colloidal state. The particles are thus stored in a lyophilized form and should be reconstituted immediately before use. Meanwhile, other factors need further consideration.

It is generally assumed that drugs on nanoparticles are released by several processes, such as diffusion through the polymer matrix, release by polymer degradation and solubilization and diffusion through microchannels that exist in the polymer matrix or are formed by erosion ${ }^{[21]}$. Because of the long biodegradation time of PLGA, we assume that the drug would be released from the nanoparticles through the diffusion mechanism in vitro. This hypothesis requires further investigation.

The cytotoxicity of $\mathrm{MgFe}_{2} \mathrm{O}_{4}$ was minor according to the MTT experiment result. The absorbance was essentially unchanged after the Saos-2 cells were administered with non$\mathrm{As}_{2} \mathrm{O}_{3}$-loaded MNPs for $48 \mathrm{~h}$. The MTT result also illustrated that the growth inhibition of Saos-2 cells by $\mathrm{As}_{2} \mathrm{O}_{3}$ was timeand dose-dependent. The enhanced inhibition of cell growth after administering $\mathrm{As}_{2} \mathrm{O}_{3}$-loaded MNPs might be caused by the higher concentration of $\mathrm{As}_{2} \mathrm{O}_{3}$ induced by the magnetic field in flat-bottom plates. This is supported by the result that the $\mathrm{IC}_{50}$ of $\mathrm{As}_{2} \mathrm{O}_{3}$ solution was 2.57 times higher than that of the $\mathrm{As}_{2} \mathrm{O}_{3}$-loaded MNPs at $48 \mathrm{~h}$.

The $\mathrm{C}_{\max }$ of $\mathrm{As}_{2} \mathrm{O}_{3}$ in liver tissue in the magnetic group was $30.65 \mu \mathrm{g} / \mathrm{g}$, 4.17 times the drug concentration in kidney tissue from the same experimental group $(7.35 \mu \mathrm{g} / \mathrm{g})$, and 2.88 times the drug concentration in liver tissue of the non-magnetic group $(10.66 \mu \mathrm{g} / \mathrm{g})$. These results indicated that $\mathrm{As}_{2} \mathrm{O}_{3}-\mathrm{MNPs}$ in normal mice showed good magnetic targeting. At the same time, the concentration of $\mathrm{As}_{2} \mathrm{O}_{3}$ was lower in the kidney tissue, thereby leading to a reduced effect of the drug in kidney functions and reduced toxicity in other organs. 
Suitable particle size of the magnetic media generally ranges between $10 \mathrm{~nm}$ and $30 \mathrm{~nm}$, and the particles are subjected to an external magnetic field and accurately positioned in the target therapy site and its surrounding tissue. The magnetic materials $\left(\mathrm{MgFe}_{2} \mathrm{O}_{4}\right)$ used in the experiment were $10 \mathrm{~nm}$ in size and had good magnetic response, stability and no obvious toxicity, as shown in the animal experimentation in the present study. If their safety can be further established, Mg-Fe Ferrite could be a new type of targeting vector for magnetically targeted drugs.

In our experiment, the $\mathrm{As}_{2} \mathrm{O}_{3}$-MNPs showed good stability in its structure, entrapment efficiency and drug loading. Their high capability of magnetic targeting was illustrated in vivo, which indicated that the agent complies with the requirements of targeted drugs.

\section{Acknowledgements}

This project was supported by Science and technology key projects of Heilongjiang province (№ GC08C421).

\section{Author contribution}

Guo-fu YANG designed research; Wen-bo WANG performed research; Xiang-hui LI contributed new analytical tools and reagents; Zhe ZHAO analyzed data; Guo-fu YANG wrote the paper.

\section{References}

1 Lew YS, Brown SL, Griffin RJ, Song CW, Kim JH. Arsenic trioxide causes selective necrosis in solid murine tumors by vascular shutdown. Cancer Res 1999; 59: 6033-7.

2 Ghavamzadeh A, Alimoghaddam K, Ghaffari SH, Rostami S, Jahani M, Hosseini R, et al. Treatment of acute promyelocytic leukemia with arsenic trioxide without ATRA and/or chemotherapy. Ann Oncol 2006; 17: 131-4.

3 Slack JL, Waxman S, Tricot G, Tallman MS, Bloomfield CD. Advances in the management of acute promyelocytic leukemia and other hematologic malignancies with arsenic trioxide. Oncologist 2002; 7: 1-13.

4 Zhou GB, Zhang J, Wang ZY, Chen SJ, Chen Z. Treatment of acute promyelocytic leukaemia with all-trans retinoic acid and arsenic trioxide: a paradigm of synergistic molecular targeting therapy. Phil Trans R Soc B 2007; 362: 959-71.

5 Zhu J, Chen Z, Lallemand-Breitenbach V, de Thé H. How acute promyelocytic leukaemia revived arsenic. Nat Rev Cancer 2002; 2: 1-9.

6 Gielen M, Tiekink ER. Metallotherapeutic drugs and metal-based diagnostic agents. Wiley; 2005. p 298.

7 Griffin RG, Williams BW, Park HJ, Song CW. Preferential action of arsenic trioxide in solid-tumor microenvironment enhances radiation therapy. Int J Radiat Oncol Biol Phys 2005; 61: 1516-22.

8 Zhou J, Meng R, Sui X, Meng L, Jia J, Yang B. Effects of administration styles of arsenic trioxide on intracellular arsenic concentration, cell differentiation and apoptosis. Haematologica 2005; 90: 1277-9.

9 Tun-Kyi A, Qin JZ, Oberholzer PA, Navarini AA, Hassel JC, Dummer R, et al. Arsenic trioxide down-regulates antiapoptotic genes and induces cell death in mycosis fungoides tumors in a mouse model. Ann Oncol 2008; 19: 1488-94.

10 Catarina PR, Ronald JN, António J R, Francisco V. Nanoencapsulation I. Methods for preparation of drug-loaded polymeric nanoparticles. Nanomedicine 2006; 2: 8-21.

11 Du L, Chen JZ, Qi YT, Li D, Yuan CG, Lin MC, et al. Preparation and biomedical application of a non-polymer coated superparamagnetic nanoparticle. Int J Nanomed 2007; 2: 805-12.

12 Sunho P, Kimberly HS. Evaluation of hydrodynamic size and zetapotential of surface-modified au nanoparticle-dna conjugates via ferguson analysis. J Phys Chem 2008; 112: 7611-6.

13 Liu WY. Pharmaceutical analysis. Beijing: People's Medical Publishing House; 2007. 5th edition: p 287-336.

14 Montoro E, Lemus D, Echemendia M, Martin A, Portaels F, Carlos Palomino J. Comparative evaluation of the nitrate reduction assay, the MTT test, and the resazurin microtitre assay for drug susceptibility testing of clinical isolates of Mycobacterium tuberculosis. J Antimicrob Chemother 2005; 55: 500-5.

15 Chou WC, Dang CV. Acute promyelocytic leukemia: recent advances in therapy and molecular basis of response to arsenic therapies. Curr Opin Hematol 2005; 12: 1-6.

16 Miller WH Jr, Schipper HM, Lee JS, Singer J, Waxman S. Mechanisms of action of arsenic trioxide. Cancer Res 2002; 62: 3893-903.

17 Chun W, Phuong-Truc P. Polymers for viral gene delivery. Expert Opin Drug Deliv 2008; 5: 385-401.

18 Stevanovi M, Uskokovi D. Poly(lactide-co-glycolide)-based micro and nanoparticles for the controlled drug delivery of vitamins. Curr Nanosci 2009; 5: 1-15.

19 Chen ZP, Zhang Y, Xu K, Xu RZ, Liu JW, Gu N. Stability of hydrophilic magnetic nanoparticles under biologically relevant conditions. J Nanosci Nanotechnol 2008; 8: 6260-5.

20 Yue PF, Yuan HL, Yang M, You RH, Cong LB, Zhu J, et al. Preparation, characterization, and pharmacokinetic evaluation of puerarin submicron emulsion. PDA J Pharm Sci Technol 2008; 62: 32-45.

21 Wong HL, Bendayan R, Rauth AM, Xue HY, Babakhanian K, Wu XY. A mechaninstic study of enhanced doxorubicin uptake and potention in multidrug resistant breast cancer cells using a polymer-lipid hybrid nanoparticles system. J Pharmacol Exp Ther 2006; 317: 1372-81. 